\title{
Effect of somatic cell count level on functional longevity in Valle del Belice dairy sheep assessed using survival analysis
}

\author{
V. Riggio, ${ }^{\star} \dagger^{1}$ D. O. Maizon, ${ }^{\star} \ddagger$ B. Portolano, ${ }^{*}$ H. Bovenhuis, $\dagger$ and J. A. M. van Arendonk $\dagger$ \\ *Dipartimento S.En.Fi.Mi.Zo.-Sezione Produzioni Animali, Università degli Studi di Palermo, Viale delle Scienze-Parco d'Orleans, \\ 90128 Palermo, Italy \\ †Animal Breeding and Genomics Centre, Wageningen University, PO Box 338, $6700 \mathrm{AH}$ Wageningen, the Netherlands \\ ‡Instituto Nacional de Tecnología Agropecuaria, EEA Anguil, CC 11, 6326 La Pampa, Argentina
}

\begin{abstract}
The objectives of this study were to evaluate the effect of somatic cell count (SCC) on functional longevity and to estimate the heritability of functional longevity using survival analysis in Valle del Belice dairy sheep. A total of 4,880 lactations of 2,190 ewes from 11 flocks were used. In this study, SCC was considered as an indication of subclinical mastitis. In case of clinical cases, identified by the technicians at milking time, test-day weights and milk samples of those ewes were not considered. Somatic cells were analyzed as counts, without any transformation, and were grouped in 3 classes based on the observed SCC maximum (mxSCC). The mxSCC classes, expressed as $10^{3}$ cells $/ \mathrm{mL}$, were classified as 1 if $\operatorname{mxSCC} \leq 500,2$ if $500<\mathrm{mxSCC}<1,000$, and 3 if $\mathrm{mx}-$ $\mathrm{SCC} \geq 1,000$. An increase in SCC was associated with an increased hazard of being culled. Ewes in the highest class of SCC on a test-day had a $20 \%$ higher hazard of being culled than those in the lowest class. Therefore, SCC played a role in culling decisions of Valle del Belice dairy sheep farmers. The heritability estimate for functional longevity was $7 \%$ on the logarithmic scale and $11 \%$ on the real scale, indicating that selection for this trait is possible in sheep. The flock-year-season effect explained $19 \%$ of the variation on the logarithmic scale and $27 \%$ of the variation on the real scale.
\end{abstract}

Key words: somatic cell count, longevity, survival analysis, dairy sheep

\section{INTRODUCTION}

Intramammary infections are the primary cause of mastitis in dairy ewes and cows. Mastitis leads to economic losses, mainly arising from discarded milk, reduced milk production and quality, and increased health care costs both in dairy ewes (Leitner et al., 2004) and cows (e.g., Wellenger et al., 2002). Albenzio

Received April 30, 2008.

Accepted September 8, 2009.

${ }^{1}$ Corresponding author: vriggio@unipa.it et al. (2002) reported a reduction in fat and casein content in ewes infected by mastitis. Almost all sheep milk is processed into cheese; thus, any change in casein content would have a substantial effect on the industrial value of the milk.

Legarra et al. (2007) reported that increased susceptibility to mastitis is one of the reasons for culling in sheep. However, little information is available about the relationship between longevity and both clinical and subclinical mastitis in sheep. Bergonier and Berthelot (2003) reported that annual incidence of clinical mastitis in sheep is generally less than $5 \%$, whereas the prevalence of subclinical mastitis ranges from less than 10 to more than 50\%. Barillet et al. (2001) reported a $5 \%$ frequency of culling for clinical mastitis and a $9.7 \%$ frequency for subclinical mastitis as predicted by SCC. In cattle, the incidence of mastitis has an important effect on culling decisions (e.g., Neerhof et al., 2000), particularly mastitis that occurs before the time of peak milk yield (Beaudeau et al., 1994). Antagonistic genetic correlations for longevity with mastitis resistance, ranging from 0.22 to 0.53 , were found in dairy cows (Nielsen and Pedersen, 1995; Mrode et al., 2000; Roxström and Strandberg, 2002).

Mastitis causes an increase in SCC in small ruminants (Zeng et al., 1997; Leitner et al., 2004) and cattle (e.g., Heringstad et al., 2006). Moreover, mastitis data are difficult and expensive to collect, whereas SCC is currently recorded in several milk recording schemes in both dairy sheep (Astruc et al., 2004) and cattle (Boettcher, 2005). Therefore, SCC is promoted as an indirect method of predicting mammary infections and as a selection criterion to improve mastitis resistance (Heringstad et al., 2000; Barillet, 2007). However, Legarra et al. (2007) considered the measure of SCC as an indicator of subclinical mastitis. Whereas clinical mastitis is generally identified by evident signs, subclinical mastitis is usually inferred from SCC (Bergonier and Berthelot, 2003).

In dairy cattle, the effect of SCC on culling at the phenotypic level was first assessed by Beaudeau et al. (1995). Previous studies, using survival analysis, 
reported that higher concentrations of SCC were associated with higher rates of culling (Samoré et al., 2003; Caraviello et al., 2005). Antagonistic genetic correlations between SCC and longevity, ranging from 0.16 to 0.36 , have been reported for dairy cows (Nielsen and Pedersen, 1995; Mrode et al., 2000; Roxström and Strandberg, 2002), indicating that elevated SCC is associated with reduced longevity. However, information regarding the relationship between SCC and functional longevity is lacking in sheep. Legarra et al. (2007) suggested that a much more detailed study on culling policies and relationships between SCS, SCC, mastitis, and survival in dairy sheep is needed.

Longevity corrected for milk production level, functional longevity, is an approximate measure for involuntary culling (Dekkers, 1993). At present, only a few estimates of heritability for longevity are available in dairy sheep (Conington et al., 2001; El-Saied et al., 2005).

The objectives of this study were to evaluate the effect of SCC as an indirect measure of subclinical mastitis on functional longevity, and to estimate the heritability of functional longevity in Valle del Belice dairy ewes.

\section{MATERIALS AND METHODS}

\section{Data}

The original data set consisted of 6,530 lactations of 3,219 ewes. Data for SCC were collected at approximately 1-mo intervals by the University of Palermo (Italy) in 17 Valle del Belice flocks between 1998 and 2006; SCC was measured only when ewes were free of clinical mastitis. The Valle del Belice breed is the most productive autochthonous breed reared in Sicily. At milking time, cases of clinical mastitis were identified by the technicians and test-day weights and milk samples of those ewes were not considered. Clinical mastitis was reported for the evident signs of udder inflammation, or abnormal milk, or both. Most cases of mastitis were confirmed by a veterinarian. Records were excluded when SCC information was missing, ewes had missing sire identification, or ewes were sired by rams with fewer than 4 female offspring. Moreover, records were left out when the age at first lambing was not in the range of 10 to $30 \mathrm{mo}$ and when they were from flocks with observations for a period of less than $2 \mathrm{yr}$. After editing, the data set consisted of 4,880 lactation records from 2,190 ewes reared in 11 flocks. The average number of SCC test-days was 3.5 per lactation.

The response variable was the productive life defined on a lactation basis, either from one lambing to the next or to culling, whichever came first, in accordance with Roxström et al. (2003). In this analysis, the overall longevity for a given ewe was partitioned into lactation periods; consequently, all records began with a lambing. In cases where ewes were not culled during a specific lactation period, records were treated as right censored. Ewes were considered culled, and therefore records were considered uncensored, if the last test-day reported was at least 6 mo before the end of the observation period for each flock. The 6 -mo period was chosen by considering the intervals between lambings and the possibility that a ewe was in a dry period.

\section{Statistical Analysis}

The analysis was performed with a survival analysis (Ducrocq and Casella, 1996) using the Survival Kit 3.0 set of programs (Ducrocq and Sölkner, 1998a). A Weibull model, less computationally demanding compared with the Cox model, was used. The Weibull distribution assumption was checked by plotting $\ln [-\ln S(t)]$ against $\ln (t)$, where $S(t)$ was the Kaplan-Meier estimate of the survivor function, ln was natural logarithm, and $t$ was the number of days from lambing within lactation.

The following Weibull model was used:

$$
\begin{gathered}
h_{i j l m n o p}(t)=h_{0}(t) \exp \left[s l_{i}(t)+o p_{j}+a g e_{l}+m k_{m}(t)\right. \\
\left.+s c c_{n}(t)+f y s_{o}+s_{p}\right],
\end{gathered}
$$

where $h_{i j l m n o p}(t)$ was the hazard of culling for a given ewe at time $t$, being $t$ days from lambing within a lactation; $h_{0}(t)$ was the Weibull baseline hazard function, with scale parameter $\lambda$ and shape parameter $\rho ; s l_{i}(t)$ was the time-dependent fixed effect of the $i$ th stage of lactation. Five classes were defined as 1 when $0<$ DIM $\leq 60$, 2 when $60<$ DIM $\leq 120$, 3 when $120<$ DIM $\leq$ 180,4 when $180<\mathrm{DIM} \leq 250$, and 5 when DIM $>250$. The stage of lactation effect was included to account for changes in the culling hazard within lactation. $o p_{j}$ was the time-independent fixed effect of the $j$ th parity, with $j=1, \ldots, 5$. $a g e_{l}$ was the time-independent fixed effect of the $l$ th age at first lambing class, where $l=1$ when first lambing occurred at 10 to 18 mo of age, 2 at 19 to 23 mo of age, and 3 at 24 to 30 mo of age. When the information about the age at first lambing was missed, such as when ewes were recorded from a second or later lactation, the age at first lambing was approximated by considering a fixed interval between parities equal to $365 \mathrm{~d} . m k_{m}(t)$ was the time-dependent fixed effect of the $m$ th class for average daily milk production, expressed as milk deviations (milk_dev) from the mean and standardized by the corresponding standard deviation within stage of lactation and flock. The milk deviations were assumed to be piecewise constant from the beginning to the end of a given stage of lacta- 
tion. Three classes were considered: $m=1$ if milk_dev $<-1, m=2$ if $-1<$ milk_dev $\leq 1$, and $m=3$ if milk_dev $>1 . s c c_{n}(t)$ was the time-dependent fixed effect of the $n$th class, based on the observed SCC maximum ( $\mathbf{m x S C C})$ within a stage of lactation; it was assumed to be piecewise constant from the beginning to the end of a given stage of lactation. The mxSCC classes, expressed as $10^{3}$ cells $/ \mathrm{mL}$, were classified as 1 if $\operatorname{mxSCC} \leq 500$ (with 3,690 records), 2 if $500<\operatorname{mxSCC}$ $<1000$ (with 1,409 records), and 3 if $\operatorname{mxSCC} \geq 1000$ (with 2,867 records). Thresholds for SCC classes were chosen according to Bergonier et al. (1994) and based on the evidence provided by other authors that healthy sheep normally have higher SCC than cows (e.g., Fthenakis et al., 1991). fys o was the time-independent random effect of the oth flock-year-season of the lambing subclass, with $o=1, \ldots, 166$ from up to 11 flocks in $9 \mathrm{yr}$ of lambing, considering 3 lambing seasons. The lambing season was equal to 1 when lambing occurred from August to November, equal to 2 from December to March, and equal to 3 from April to July (Portolano et al., 2007). A fys class was included in the analysis if there were at least 4 records within it. The fys effects were assumed to follow a log-gamma distribution with parameter $\gamma \cdot s_{p}$ was the time-independent random effect of sire $(p=1, \ldots, 168)$, assumed to be distributed as a multivariate normal with mean vector 0 and covariance matrix $A \sigma_{s}^{2}$, where $A$ was the additive relationship matrix among sires. A sire model was used.

Heritability was estimated as (Ducrocq and Casella, 1996)

$$
\hat{h}_{\log }^{2}=\frac{4 \sigma_{s}^{2}}{\psi(\gamma)+\sigma_{s}^{2}+\frac{\pi^{2}}{6}}
$$

where $\psi(\gamma)$ is the trigamma function evaluated at the estimated marginal posterior mode of the variance of the flock-year-season effect and $\pi$ is the pi constant. The effective heritability was estimated as (Yazdi et al., 2002)

$$
\hat{h}_{e f f}^{2}=\frac{4 \sigma_{s}^{2}}{\psi(\gamma)+\sigma_{s}^{2}+1} .
$$

Standard error for the effective heritability was approximated (equation 2.28 in Roff, 1997). By replacing the numerator $4 \sigma_{s}^{2}$ with $\psi(\gamma)$, we estimated the proportion of the total variation, explained by the flock-yearseason effect, on both logarithmic and real scales.
Table 1. Chi-squared $\left(\chi^{2}\right)^{1}$ tests based on likelihood ratio tests for all effects in the model

\begin{tabular}{lcrr}
\hline Effect in the model & df & \multicolumn{1}{c}{$\chi^{2}$} & $P$-value \\
\hline Stage of lactation & 4 & 113.4 & $<0.0001$ \\
Parity & 4 & 48.4 & $<0.0001$ \\
Age at first lambing & 2 & 7.1 & 0.0282 \\
Daily milk production & 2 & 121.5 & $<0.0001$ \\
Maximum SCC & 1 & 10.2 & 0.0014 \\
Flock-year-season & 1 & 309.9 & $<0.0001$ \\
Sire & 1 & 31.8 & $<0.0001$ \\
\hline
\end{tabular}

${ }^{1}$ Chi-squared is a likelihood ratio test; that is, the difference between the $-2 \log$ (likelihood) for the reduced model (without the effect tested) and the $-2 \log$ (likelihood) for the full model.

\section{RESULTS}

Longevity for a given ewe was partitioned into lactations and, by consequence, about $76.4 \%$ of the records were right censored. The average lactation length, considering the entire data set (culled and not culled animals), was $171 \pm 72 \mathrm{~d}$ whereas the lactation length of animals that were not culled was $250 \pm 35 \mathrm{~d}$. The daily average of milk yield was $1,310 \mathrm{~g}$ whereas the average test-day SCC was $1,932 \times 10^{3}$ cells $/ \mathrm{mL}$.

The fitted model explained approximately $50 \%$ of the total variation in the response variable. The shape parameter $\rho$ was equal to 1.33 , indicating that as time increased within lactation, so did the hazard of culling. The plot used to check the Weibull distribution assumption, $\ln [-\ln S(t)]$ versus $\ln (t)$, showed a straight line (results not shown), an indication that this assumption was valid.

Chi-square test approximations based on likelihood ratio test were calculated for all the effects in the model (Table 1). The significance of each effect resulted from the corresponding $P$-value.

Estimates of time-independent fixed effects indicated that ewes at second lambing were at a lower hazard of being culled than ewes at first lambing (Table 2). Relatively more culling in first parturition might be explained by culling for low production or culling for lambing difficulties, especially for ewes having the first lambing at an early age. Moreover, ewes at the fourth or greater lambing were at a higher hazard than ewes at the first lambing. The effect of age at first lambing resulted, in general, in an increase in culling rate with age.

Table 3 shows the estimates of time-dependent fixed effects. The estimates for the first to fourth classes of stage of lactation were significantly different from 1 , indicating that ewes in these classes were at a higher hazard of being culled than those in the fifth class, the reference level. Ewes in the first and second classes of milk production were at a higher hazard of being culled than those in the third (reference) class with greatest 
Table 2. Mode $(\hat{b})$ and standard deviation $\left(\hat{\sigma}_{\hat{b}}\right)$ of the marginal posterior distributions, hazard ratio $(\hat{h})$ based on posterior modes, and $95 \%$ confidence interval (CI) for $\hat{h}$ with lower and upper bounds for the timeindependent fixed effects, estimated with the model including SCC

\begin{tabular}{|c|c|c|c|c|c|c|}
\hline \multirow[b]{2}{*}{ Effect $^{1}$} & \multirow[b]{2}{*}{ Class } & \multirow[b]{2}{*}{$\hat{b}$} & \multirow[b]{2}{*}{$\hat{\sigma}_{\hat{b}}$} & \multirow[b]{2}{*}{$\hat{h}$} & \multicolumn{2}{|c|}{$95 \%$ CI for $\hat{h}$} \\
\hline & & & & & Lower & Upper \\
\hline \multirow[t]{5}{*}{ Parity } & 1 & 0 & - & 1 & - & - \\
\hline & 2 & -0.216 & 0.093 & 0.805 & 0.672 & 0.966 \\
\hline & 3 & -0.095 & 0.107 & 0.909 & 0.738 & 1.121 \\
\hline & 4 & 0.237 & 0.115 & 1.268 & 1.013 & 1.588 \\
\hline & 5 & 0.608 & 0.121 & 1.837 & 1.450 & 2.328 \\
\hline \multirow{3}{*}{ Age at first lambing } & 1 & 0 & - & 1 & - & - \\
\hline & 2 & 0.107 & 0.083 & 1.113 & 0.945 & 1.311 \\
\hline & 3 & 0.236 & 0.087 & 1.266 & 1.066 & 1.502 \\
\hline
\end{tabular}

${ }^{1}$ Parity $=1$ and age at first lambing $=1$ were used as reference levels.

milk yields. Regarding SCC, ewes in the second and third classes were at a higher hazard of being culled than those in the first class with the least SCC.

Table 4 shows the estimates for the time-independent random effects, heritabilities for productive life, and proportion of variation explained by the flock-yearseason effect obtained with the Weibull model. The heritability of productive life was 0.07 on the logarithmic scale and 0.11 on the real scale. The proportion of variation in productive life explained by the flock-yearseason effect was 0.19 on the logarithmic scale and 0.27 on the real scale.

\section{DISCUSSION}

Prognostic factors-particularly SCC, which serve as an indirect measure of subclinical mastitis - affected productive life in Valle del Belice ewes. To our knowledge, this is the first such finding in sheep, using sur- vival analysis. Therefore, results were mostly compared with those reported for dairy cattle. A lactation basis approach was chosen because it better suited our data, which were collected on farms during different periods. Roxström et al. (2003) did not report major differences between longevity analyzed on a lactation basis and longevity based on the entire length of life.

The effect of age at first lambing resulted, overall, in an increase in culling rate with age. It is not convenient for a farmer to keep animals that are going to lamb for the first time at an advanced age. This result was in agreement with the results reported by Samoré et al. (2003) in dairy cattle. However, Chirinos et al. (2007) reported that age at first calving did not affect the hazard of culling in the Spanish Holstein-Friesian cattle population.

The effect of stage of lactation was included in the model because it allowed for better modeling of the baseline hazard and has an important factor affecting

Table 3. Mode $(\hat{b})$ and standard deviation $\left(\hat{\sigma}_{\hat{b}}\right)$ of the marginal posterior distributions, hazard ratio $(\hat{h})$ based on posterior modes, and $95 \%$ confidence interval (CI) for $\hat{h}$ with lower and upper bounds for the timedependent fixed effects, estimated with the model including SCC

\begin{tabular}{|c|c|c|c|c|c|c|}
\hline \multirow[b]{2}{*}{ Effect $^{1}$} & \multirow[b]{2}{*}{ Class } & \multirow[b]{2}{*}{$\hat{b}$} & \multirow[b]{2}{*}{$\hat{\sigma}_{\hat{b}}$} & \multirow[b]{2}{*}{$\hat{h}$} & \multicolumn{2}{|c|}{$95 \%$ CI for $\hat{h}$} \\
\hline & & & & & Lower & Upper \\
\hline \multirow[t]{5}{*}{ Stage of lactation } & 1 & 1.053 & 0.273 & 2.866 & 1.677 & 4.899 \\
\hline & 2 & 1.361 & 0.175 & 3.901 & 2.768 & 5.497 \\
\hline & 3 & 1.270 & 0.142 & 3.562 & 2.694 & 4.708 \\
\hline & 4 & 0.876 & 0.126 & 2.400 & 1.874 & 3.074 \\
\hline & 5 & 0 & - & 1 & - & - \\
\hline \multirow[t]{3}{*}{ Daily milk production } & 1 & 0.925 & 0.116 & 2.523 & 2.008 & 3.169 \\
\hline & 2 & 0.222 & 0.109 & 1.248 & 1.008 & 1.546 \\
\hline & 3 & 0 & - & 1 & - & - \\
\hline \multirow{3}{*}{ Maximum SCC } & 1 & 0 & - & 1 & - & - \\
\hline & 2 & 0.172 & 0.099 & 1.187 & 0.978 & 1.441 \\
\hline & 3 & 0.214 & 0.070 & 1.239 & 1.079 & 1.421 \\
\hline
\end{tabular}

${ }^{1}$ Stage of lactation $=5$, daily milk production $=3$, and maximum $\mathrm{SCC}=1$ were used as reference levels. 
Table 4. Mean $( \pm \mathrm{SD})$ and mode of the random effects in the model, heritabilities for the productive life on logarithmic $\left(\hat{h}_{\log }^{2}\right)$ and real $\left(\hat{h}_{\text {eff }}^{2}\right)$ scales, standard error of $\hat{h}_{\text {eff }}^{2}$, and proportion of variation explained by flock-year-season effect on logarithmic $\left(\right.$ Pfys $\left._{\log }\right)$ and real $\left(\right.$ Pfys $\left._{\text {eff }}\right)$ scales

\begin{tabular}{ll}
\hline Item & Value \\
\hline Mean $( \pm \mathrm{SD}) \sigma_{\text {sire }}^{2}$ & $0.047( \pm 0.026)$ \\
Mean $( \pm \mathrm{SD}) \sigma_{\text {fys }}^{2}$ & $3.193( \pm 0.627)$ \\
Mode $\sigma_{\text {sire }}^{2}$ & 0.039 \\
Mode $\sigma_{\text {fys }}^{2}$ & 3.041 \\
$\hat{h}_{\log }^{2}$ & 0.07 \\
$\hat{h}_{\text {eff }}^{2}$ & 0.11 \\
SE $\left(\hat{h}_{\text {eff }}^{2}\right)$ & 0.025 \\
Pfys $_{\log }$ & 0.19 \\
Pfys $_{\text {eff }}$ & 0.27 \\
\hline
\end{tabular}

culling. Ewes in middle lactation (i.e., 60-180 d) had a higher hazard of being culled compared with those in late lactation. When referring only to culling because of mastitis, a review by Bergonier et al. (2003) showed that in sheep, the majority of cases of mastitis occur during the first third of lactation. In dairy cattle, Beaudeau et al. (1995) and Roxström et al. (2003) reported an increased hazard of culling in early lactation.

The estimates for the classes of daily milk production showed that ewes with a level of production below the flock average had a higher hazard of being culled, in agreement with research results in cattle (e.g., Vukasinovic et al., 2001; Chirinos et al., 2007).

Ewes with a maximum SCC between 500 and 1,000 or $\geq 1,000 \times 10^{3}$ cells $/ \mathrm{mL}$ in a stage of lactation had a slightly higher hazard of being culled than ewes with lesser maximums. These estimates were in the same direction as those reported by Beaudeau et al. (1995) in dairy cows, with a range of 1.7 from the highest to lowest class for SCC, whereas they were much lower than those reported by Samoré et al. (2003). Samoré et al. (2003) considered SCS instead of SCC, reporting a 3 -fold higher rate of culling for cows with test-days in the highest classes of SCS. However, using SCC or SCS is equivalent when classes are used. The transformation of SCC into SCS, therefore, would not have changed these classes because the particular transformation that is used to go from SCC to SCS is a one-to-one function. The risk associated with SCC level estimated in this study was less and might be explained by the fact that most Valle del Belice farmers do not directly use SCC information to make culling decisions for animals. In sheep, the current milk payment system of most countries is based only on milk yield and not on SCC level, which is different from the cattle industry. However, Valle del Belice sheep milk is mainly used for producing raw-milk traditional cheeses (Pecorino and Vastedda del Belice cheeses) either by farms, small local dairies, or cheese industries working at the regional level. Therefore, an indirect effect of SCC on culling can be considered because SCC has a remarkable influence on the bulk milk composition and lactodynamographic parameters of Valle del Belice sheep (Giaccone et al., 2005). Moreover, the genetic correlations between milk production traits (milk yield and fat and protein yields and contents) and SCS level in Valle del Belice sheep are positive, ranging from 0.16 to 0.31 (Riggio et al., 2007). However, Bufano et al. (1994) showed that high SCC $(>1$ million $/ \mathrm{mL})$ do occur in normal sheep milk, especially toward the end of lactation, whereas Bergonier et al. (2003) showed that nonpathological factors are responsible for variations of SCC in ewe milk between $40 \times 10^{3}$ and $100 \times 10^{3}$ cells $/ \mathrm{mL}$.

Considering SCC as an indicator of subclinical mastitis, these results may be compared with studies analyzing the rate of culling directly associated with mastitis incidence. Beaudeau et al. (1995) found that udder health disorders were always highly related to an increase in culling rate in dairy cows. Legarra et al. (2007), in a study to derive the economic value of SCS in dairy sheep, reported that SCS had an effect on culling decision. In the present study, the economic weight of culling was considered indirectly based on the genetic correlations between SCS level and the culling because of subclinical mastitis. A genetic increase of 1 unit of SCS increases the trait "culled by mastitis" in 0.12 times the genetic correlation.

The flock-year-season effect was an important factor explaining the observed variation in productive life. This result was in agreement with the results from other studies on Valle del Belice sheep (Portolano et al., 2007; Riggio et al., 2007), confirming the importance of this factor. Milking practices might be an important factor in influencing udder health. In Sicily, only a few farmers use a milking machine; most farmers milk ewes by hand. It is not common for farmers to wash ewes' udders or their hands before milking. Moreover, antibiotic dry therapy is not implemented on all farms. This variability is reflected in different hygiene conditions among farms, which can influence milk quality.

Literature concerning sheep reports heritability estimates for functional longevity somewhat lower than those presented in this study. El-Saied et al. (2005) 
reported a heritability of 0.05 for functional longevity in the Churra breed. Similar estimates of heritability for longevity, measured as days or years in the flock, were reported in the literature for meat breeds $[0.06$ for Australian Dorset sheep (Brash et al., 1994) and 0.08 for Scottish Blackface (Conington et al., 2001)]. The heritability estimated for functional longevity in this study was higher than estimates reported by Chirinos et al. (2007) in cattle, ranging between 0.05 and 0.07 , whereas Neerhof et al. (2000) and Ducrocq and Sölkner (1998b) reported heritabilities around 0.05 for the logarithmic scale and 0.22 for the real scale.

\section{CONCLUSIONS}

An increase in SCC as an indicator of subclinical mastitis was associated with an increase in rate of culling. Therefore, elevated SCC arising from subclinical mastitis played an indirect role in the culling decisions of Valle del Belice dairy sheep farmers although, at present, they do not select directly to reduce SCC. The proportion of additive genetic variation estimated for functional longevity in Valle del Belice ewes indicates that it may be possible to improve productive life by genetic selection. The consistent flock-year-season effect estimated confirms the high variability in management of the Valle del Belice breed.

\section{ACKNOWLEDGMENTS}

The authors acknowledge the Ministero delle Politiche Agricole Alimentari e Forestali (MiPAAF) (D.M. 302/7303/05), Assessorato Industria della Regione Siciliana Serv. $3^{\circ}$ (DRS 2359/2005), and Assessorato Agricoltura e Foreste della Regione Siciliana (DDG n. 1258/2006) for financial support for this research. The project funded by Ministero dell'Istruzione, dell'Università e della Ricerca, project \#2007898KYN (PRIN 2007) is also acknowledged. The second author had an experienced researcher position within a Marie Curie European Transfer of Knowledge Development project with contract number MTKD/ICT-2004-14412.

\section{REFERENCES}

Albenzio, M., L. Taibi, A. Muscio, and A. Sevi. 2002. Prevalence and etiology of subclinical mastitis in intensively managed flocks and related changes in the yield and quality of ewe milk. Small Rumin. Res. 43:219-226.

Astruc, J. M., F. Barillet, M. Fioretti, D. Gabina, E. Gootwine, A. P. Mavrogenis, F. J. Romberg, S. R. Sanna, and E. Stefanake. 2004. Report of the working group on milk recording of sheep. Pages 315322 in Proc. 34th Biennial Session of the International Committee for Animal Recording (ICAR). Vol. 113. Sousse, Tunisia.

Barillet, F. 2007. Genetic improvement for dairy production in sheep and goats. Small Rumin. Res. 70:60-75.
Barillet, F., R. Rupp, S. Mignon-Grasteau, J. M. Astruc, and M. Jacquin. 2001. Genetic analysis for mastitis resistance and milk somatic cell score in French Lacaune dairy sheep. Genet. Sel. Evol. 33:397-415.

Beaudeau, F., V. Ducrocq, C. Fourichon, and H. Seegers. 1995. Effect of disease on length of productive life of French Holstein dairy cows assessed by survival analysis. J. Dairy Sci. 78:103-117.

Beaudeau, F., K. Frankena, C. Fourichon, H. Seegers, B. Faye, and J. P. T. M. Noordhuizen. 1994. Associations between health disorders of French dairy cows and early and late culling within the lactation. Prev. Vet. Med. 19:213-231.

Bergonier, D., and X. Berthelot. 2003. New advances in epizootiology and control of ewe mastitis. Livest. Prod. Sci. 79:1-16.

Bergonier, D., R. de Cremoux, R. Rupp, G. Lagriffoul, and X. Berthelot. 2003. Mastitis of dairy small ruminants. Vet. Res. 34:689-716.

Bergonier, D., A. van deWiele, J. M. Arranz, F. Barillet, G. Lagriffoul, D. Condorcet, and X. Berthelot. 1994. Detection of subclinical mammary infections in the ewe by mean of somatic cell counts: Proposal of physiological thresholds. Pages 41-47 in Proc. Int. Symp. Somatic Cells and Milk of Small Ruminants. Bella, Italy, Sept. 25-27, 1994. EAAP Publ. No. 77. Wageningen Academic Publishers, Wageningen, the Netherlands.

Boettcher, P. 2005. Breeding for improvement of functional traits in dairy cattle. Ital. J. Anim. Sci. 4:7-16.

Brash, L. D., N. M. Fogarty, and A. R. Gilmour. 1994. Reproductive performance and genetic parameters for Australian Dorset sheep. Aust. J. Agric. Res. 45:427-441.

Bufano, G., C. Dario, and V. Laudadio. 1994. The characterisation of Leccese sheep: Variations of chemical composition and lactodynamographic parameters in milk as related to somatic cell counts. Pages 301-304 in Proc. Int. Symp. Somatic Cells and Milk of Small Ruminants. Bella, Italy, Sept. 25-27, 1994. EAAP Publ. No. 77. Wageningen Academic Publishers, Wageningen, the Netherlands.

Caraviello, D. Z., K. A. Weigel, G. E. Shook, and P. L. Ruegg. 2005. Assessment of the impact of somatic cell count on functional longevity in Holstein and Jersey cattle using survival analysis methodology. J. Dairy Sci. 88:804-811.

Chirinos, Z., M. J. Carabaño, and D. Hernández. 2007. Genetic evaluation of length of productive life in the Spanish HolsteinFriesian population. Model validation and genetic parameters estimation. Livest. Sci. 106:120-131.

Conington, J., S. C. Bishop, B. Grundy, A. Waterhouse, and G. Simm. 2001. Multi-trait selection indexes for sustainable hill sheep production. Anim. Sci. 73:413-423.

Dekkers, J. C. M. 1993. Theoretical basis for genetic parameters of herd life and effects on response to selection. J. Dairy Sci. 76:1433-1443.

Ducrocq, V., and G. Casella. 1996. A Bayesian analysis of mixed survival models. Genet. Sel. Evol. 28:505-529.

Ducrocq, V., and J. Sölkner. 1998a. The Survival Kit-V3.0; A package for large analyses of survival data. Pages 447-448 in Proc. 6th World Congr. Genet. Appl. Livest. Prod. Armidale, Australia.

Ducrocq, V., and J. Sölkner. 1998b. Implementation of a routine breeding value evaluation for longevity of dairy cows using survival analysis techniques. Pages 359-362 in Proc. 6th World Congr. Genet. Appl. Livest. Prod. Armidale, Australia.

El-Saied, U. M., L. F. De La Fuente, J. A. Carriedo, and F. San Primitivo. 2005. Genetic and phenotypic parameter estimates of total and partial lifetime traits for dairy ewes. J. Dairy Sci. 88:3265-3272.

Fthenakis, G. C., E. T. El-Masannat, J. M. Booth, and J. E. T. Jones. 1991. Somatic cell count of ewes' milk. Br. Vet. J. 147:575-581.

Giaccone, P., M. L. Scatassa, and M. Todaro. 2005. The influence of somatic cell count on sheep milk composition and cheese-making properties. Sci. Tecn. Latt. Cas. 56:247-255.

Heringstad, B., G. Klemetsdal, and J. Ruane. 2000. Selection for mastitis resistance in dairy cattle: A review with focus on the situation in the Nordic countries. Livest. Prod. Sci. 64:95-106.

Heringstad, B., D. Gianola, Y. M. Chang, J. Ødegård, and G. Klemetsdal. 2006. Genetic associations between clinical mastitis 
and somatic cell score in early first-lactation cows. J. Dairy Sci. 89:2236-2244.

Legarra, A., M. Ramon, E. Ugarte, M. D. Pérez-Guzmán, and J. Arranz. 2007. Economic weights of somatic cell score in dairy sheep. Animal 1:205-212.

Leitner, G., M. Chaffer, A. Shamay, F. Shapiro, U. Merin, E. Ezra, A. Saran, and N. Silanikove. 2004. Changes in milk composition as affected by subclinical mastitis in sheep. J. Dairy Sci. 87:46-52.

Mrode, R. A., G. J. T. Swanson, and C. M. Lindberg. 2000. Genetic correlations of somatic cell count and conformation traits with herd life in dairy breeds, with an application to national genetic evaluations for herd life in the United Kingdom. Livest. Prod. Sci. 65:113-130.

Neerhof, H. J., P. Madsen, V. Ducrocq, A. R. Vollema, J. Jensen, and I. R. Korsgaard. 2000. Relationship between mastitis and functional longevity in Danish Black and White dairy cattle estimated using survival analysis. J. Dairy Sci. 83:1064-1071.

Nielsen, U. S., and G. A. Pedersen. 1995. Relationship between nonproduction traits and survival rates in Danish dairy cows. Pages 19:1-19:13 in Proc. Open Session Interbull Ann. Mtg. Prague, Czech Republic. Interbull bulletin no.11. Sveriges Lantbruksuniv, Uppsala, Sweden.

Portolano, B., R. Finocchiaro, J. B. C. H. M. van Kaam, V. Riggio, and D. O. Maizon. 2007. Time-to-event analysis of mastitis at first-lactation in Valle del Belice ewes. Livest. Sci. 110:273-279.

Riggio, V., R. Finocchiaro, J. B. C. H. M. van Kaam, B. Portolano, and H. Bovenhuis. 2007. Genetic parameters for milk somatic cell score and relationships with production traits in primiparous dairy sheep. J. Dairy Sci. 90:1998-2003.
Roff, D. A. 1997. Evolutionary Quantitative Genetics. Chapman \& Hall, New York, NY

Roxström, A., V. Ducrocq, and E. Stranberg. 2003. Survival analysis of longevity in dairy cattle on a lactation basis. Genet. Sel. Evol. $35: 305-318$

Roxström, A., and E. Strandberg. 2002. Genetic analysis of functional, fertility-, mastitis-, and production-determined length of productive life in Swedish dairy cattle. Livest. Prod. Sci. 74:125-135.

Samoré, A. B., M. P. Schneider, F. Canavesi, A. Bagnato, and A. F. Groen. 2003. Relationship between somatic cell count and functional longevity assessed using survival analysis in Italian Holstein-Friesian cows. Livest. Prod. Sci. 80:211-220.

Vukasinovic, N., J. Moll, and L. Casanova. 2001. Implementation of a routine genetic evaluation for longevity based on survival analysis techniques in dairy cattle populations in Switzerland. J. Dairy Sci. 84:2073-2080.

Wellenberg, G. J., W. H. M. van der Poel, and J. T. Van Oirschot. 2002. Viral infections and bovine mastitis: A review. Vet. Microbiol. 88:27-45.

Yazdi, M. H., P. M. Visscher, V. Ducrocq, and R. Thompson. 2002. Heritability, reliability of genetic evaluations, and response to selection in proportional hazard models. J. Dairy Sci. 85:15631577.

Zeng, S. S., E. N. Escobar, and T. Popham. 1997. Daily variation in somatic cell count, composition and production of Alpine dairy goats. Small Rumin. Res. 26:253-260. 